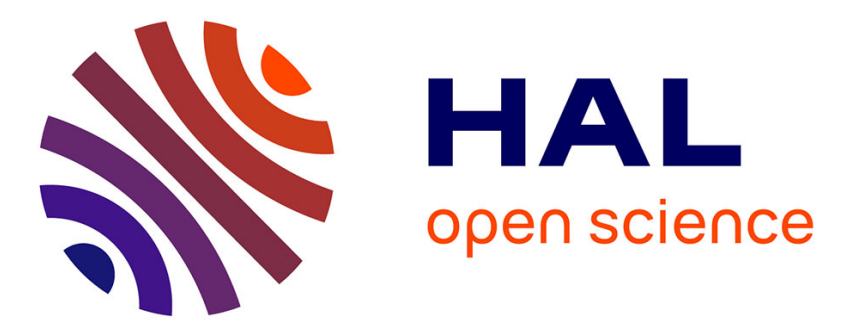

\title{
Science, technology, innovation and governance for the goat sectors \\ Jean-Paul Dubeuf
}

\section{To cite this version:}

Jean-Paul Dubeuf. Science, technology, innovation and governance for the goat sectors. 11. International Conference on Goats, International Goat Association (IGA). USA., Sep 2012, Las Palmas, Spain. hal-02807799

\section{HAL Id: hal-02807799 \\ https://hal.inrae.fr/hal-02807799}

Submitted on 6 Jun 2020

HAL is a multi-disciplinary open access archive for the deposit and dissemination of scientific research documents, whether they are published or not. The documents may come from teaching and research institutions in France or abroad, or from public or private research centers.
L'archive ouverte pluridisciplinaire HAL, est destinée au dépôt et à la diffusion de documents scientifiques de niveau recherche, publiés ou non, émanant des établissements d'enseignement et de recherche français ou étrangers, des laboratoires publics ou privés. 


\section{SCIENCE, TECHNOLOGY, INNOVATION AND GOVERNANCE FOR THE GOAT SECTORS \\ Jean-Paul DUBEUF, INRA-LRDE, UR 46, BP5, F- 20250 CORTE.}

\section{Introduction}

This article has been presented during a Conference entitled “ Industrial, scientific and rural activities in the goat sector". Linking industry, science and rurality between them and with goats could seem to be surprising. It is not really natural, nor usual. Goat activities and industry are generally seen very far from each other. And rural activities are often seen at the opposite of industrial ones! But it is probably not so anachronistic and this article has proposed to pull the threads of the new interactions between scientific knowledge, production and territorial rural issues concerning goat sectors in their diversity.

Introducing this does not begin by speaking of goats or goat products or goat producers. Goat activities will be considered as a part of the all livestock sectors and agriculture. So, it is relevant to start by identifying what challenges the world is facing, what changes are needed and some prospective approaches, at what level agriculture and animal products are concerned. Then, how innovation could be promoted by developing collaboration between science and other stake holders will be shown. We will develop at what extent this approach could be mobilized to strengthen the goat activities as one of the solutions for future.

\section{The present challenges of agriculture and animal production: Agriculture at the Cross roads}

It is trivial to say the world is now facing a global crisis in nearly all sectors. To consider and analyze this crisis, the world we could choose between two main hypotheses:

- The first one is most related to the concept of economic crisis itself. Economic crisis would be recurring cycles [1]. We would be on a growing line and we are facing some hard but limited difficulties that we could solve by developing more technology and by adaptation.

- The second one is that our development model is facing a systemic breakdown and that we have to change our basic paradigms. We choose here this second hypothesis. To sum up why, we use the main assessment of the famous economist Tim Jackson [2], often seen as the "guru” of anti growth subversive people: for him, "an economy predicated on the perpetual expansion of debt-driven materialistic consumption is unsustainable ecologically, problematic socially, and unstable economically in a world with limited resources".

Until now, the only answers of our European and North American public powers to face the difficulties and crisis, have been to find the ways to restore growth, and for the Southern one how to keep a double digit growth. It is mainly due to the fact that our present paradigm is the religion of growth: Growth would create more wealth, more jobs, more happiness and prosperity; technological innovation would not have limit; concerning science and scientific research, it would mechanically favor innovation and technological innovation would favor growth, etc...

The problem is that it does not work anymore. The challenges of agriculture and animal production cannot be faced only by more intensification and more technology. 
- It is true that the Green Revolution enabled to multiply the grain production by 3, the milk production by 5 and to feed a human world population growing from 1 billion people to 7 billion in 2 centuries only.

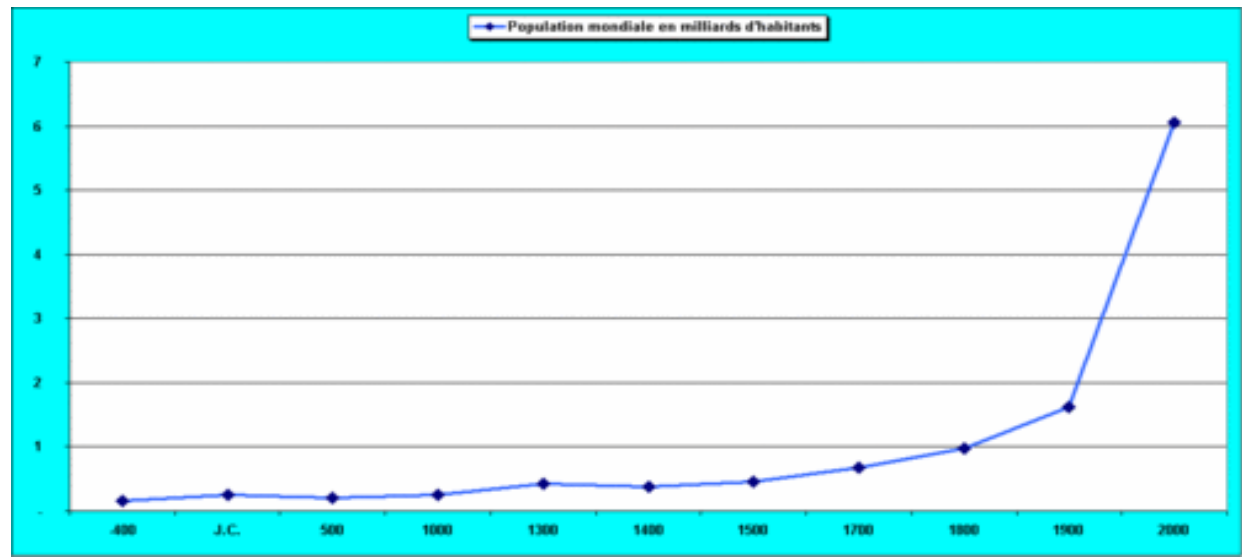

The human world population since antiques ages

- This human growth has followed the growth of yield and inputs in Agriculture. Since 1960 irrigation has doubled; the use of Nitrogen was multiplied by 7, of phosphorus by 2 and pesticides by 4 . The results have been fantastic with a highest average production of cereal and wheat per human being.
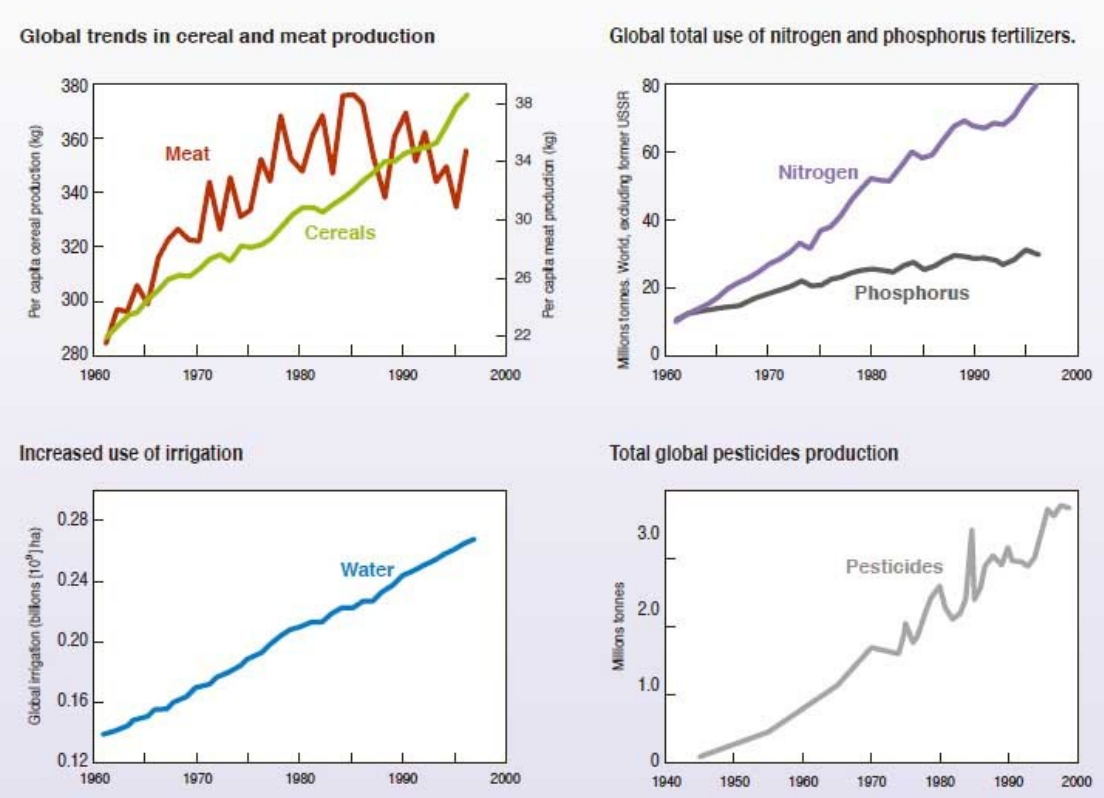

Thanks to huge consultations decided by international organizations as the World Bank, OECD, FAO and the United Nations, we know that following this way is no more possible. The International Assessment of Agricultural Knowledge, Science and Technology for Development (IAASTD) has worn a clear diagnosis later used to define the Millenium Development Goals (MDG). Agriculture is at a crossroads and a new paradigm must give the way [3].The Agricultural Knowledge, Sciences and Technologies (AKST) have contributed to increase the agricultural production and food safety. The net food availability per capita has been from $2360 \mathrm{kcal}$ in the 60's to reach $2803 \mathrm{kcal}$ now. But in spite of this amazing success the negative externalities are dramatic and threaten the sustainability of our environment and productivity: 1.9 billions ha (feeding 2 billion people) are facing high levels of soil 
degradation; agriculture and animal production are responsible of $60 \%$ of the emissions of anthropogenic methane and due to the fertilizers huge coastal areas and lakes are nearly dead due to eutrophication. Specialization and intensification have caused the decrease of the soil fertility, the use of non fertile lands, rural migration and the degradation of ecosystems. IAASTD has enhanced that a 75\% growth of grain demand is expected and a doubling of the meat demand between 2000 and 2050. Their conclusions are clear. The AKST must be more increased and strengthened but differently. By nature, agriculture has been based on the renewed fertility enabled by the balance between crops and animal production with complex and multifunctional systems. The multi functionality of Agriculture has been forgotten and agro-ecological sciences must be developed to stabilize and re -improve productivity.

The opposition between an industrial intensified, "developed" agriculture and a developing one dedicated to poor people in marginal lands has no more meaning and all the systems are concerned. Significant progresses in favor of poor farmers and small holders are as much necessary and will be as much efficient to create ecologically and socially viable ecosystems! It is so useful to investigate explain what types of innovative devices could be implemented and how.

\section{Toward a new agro - ecological paradigm based on food security to promote innovation}

Once observed that the paradigm of progress does not work anymore ${ }^{1}$, by which one replaces it? Several authors, suggest to link food security, rural development, collective and individual prosperity.

This paradigm is related to agro - ecology and to the concept of an agro -system composed by interaction with the environment. Agroecology is an approach of Agriculture considering the systems by its interactions, his balances and combining technical, social political aspects. Agroecology is not against intensification but for an ecological intensification based on human skills and valorization of renewable resources not on not renewable inputs. In many cases, it would mean to favor small holders and promote biodiversity.

But we must not underestimate the difficulties to impose it. The industrial lobbies are generally against this approach. It could weaken their position and could consider it is unrealistic.

Do not forget that our socio -technical networks are often locked in without being aware of it. Gowan and Gunby [6] have shown that a network of actors produce rules, standards, conceptions without clear awareness. A technology would not be chosen because it is more efficient individually but because it enables economies of scale, for instance by training effects (more technicians are trained, more a technology will be used) and because more numerous will be its potential of diffusion in bigger networks, more the technology would appear useful

This approach changes the position of science which is not any more a sacred activity included in the holy Trinity Research-Innovation and Growth [7]. A relevant research is a research related to operational problems so necessary multidisciplinary including social, economic and technical questions not academic. Only such a research could consider these questions globally and develop innovation systems.

\section{The several approaches of innovation as a way to consider the problems}

1 Growth always create more wealth, more jobs, more happiness and prosperity 
The approach of innovation has changed drastically since 50 years. The first model of innovation was linear. This model, we could sum up as "Diffusion and adoption" was the dominant one between 1960 and 1970. This model is related to the growth paradigm. Innovation comes from outside. "fundamental sciences" produce "applied science" used for "education and extension" then proposed to the farmers that have only to accept it. Unfortunately, this old model is not really dead and is very often still in the minds of many people.

A response to the limits of linear and adoption model has been a more holistic view of what happens on farms; This second model often developed between 1970 and 1990 has a Farming systems research perspective (FSR) and has began to develop the partnership between technical and social science.

The Agricultural Knowledge and Information System perspective (AKIS) emerged after 1990 from an extension perspective and is based on interactive learning with consciousness of a broader institutional environment

The Agricultural Innovation system (AIS) has been promoted for instance by many international institutions like the World Bank after 2000. It is seen as a network of organizations, enterprises and individuals focused on bringing new processes and new products including technological and organizational innovation. AIS has a dynamic view and is seen as a complex adaptive system. It is composed of a set of function to be fulfilled as a prerequisite or pre-conditions for innovation. In the more recent approaches, more attention has been given to resistance and political processes

\begin{tabular}{|c|c|c|c|c|}
\hline $\begin{array}{l}\text { Innovation } \\
\text { model }\end{array}$ & $\begin{array}{c}\text { "Diffusion and } \\
\text { adoption" }\end{array}$ & FSR & AKIS & AIS \\
\hline Era & $1960 / 1970$ & $1970-1990$ & $1990 / 2000$ & $2000 / .$. \\
\hline Mental model & $\begin{array}{c}\text { Application } \\
\text { technology pipe } \\
\text { line }\end{array}$ & Survey & $\begin{array}{c}\text { Collaboration } \\
\text { and partnership }\end{array}$ & $\begin{array}{c}\text { Co development } \\
\text { Innovation in } \\
\text { partnership }\end{array}$ \\
\hline $\begin{array}{c}\text { Relation } \\
\text { disposal }\end{array}$ & $\begin{array}{c}\text { Single; } \\
\text { descendant }\end{array}$ & $\begin{array}{c}\text { Multi } \\
\text { disciplinary }\end{array}$ & $\begin{array}{c}\text { Inter } \\
\text { disciplinary }\end{array}$ & $\begin{array}{c}\text { Trans } \\
\text { disciplinary }\end{array}$ \\
\hline $\begin{array}{c}\text { Relation } \\
\text { between } \\
\text { Instience and }\end{array}$ & $\begin{array}{c}\text { Science and } \\
\text { Institutions are } \\
\text { independent } \\
\text { from each other }\end{array}$ & Idem & $\begin{array}{c}\text { Science is } \\
\text { developed in a } \\
\text { historically } \\
\text { social Contest }\end{array}$ & Idem \\
\hline
\end{tabular}

Summary of the main innovation systems (from Klerck, 2012)

\section{How the goat activities are concerned by these approaches: what scientific and development priorities!}

Let us come back on goats. Goat activities and sectors are fully involved in these sectorial innovation systems approaches and the global challenges we have described upstairs.

One important side of ecological intensification is the use and improvement of interstitial and "marginal" lands and spaces often ignored until now. Goats are known to be well adapted to use scrubs, forage trees, rangelands but also sub products and interstitial spaces between the crops. Goats could contribute still marginally but significantly to answer the growing demand for meat without using arable lands, and prevent expulsion of thousands of small farmers to create huge feed lots as it is the case presently for instance in Uruguay, Argentina or Paraguay with the boom of beef. The contribution of goats to dairy marketed production would keep 
probably more limited to niche markets but their contribution to food safety in many rural areas is constantly growing.

An important realty has been identified for many years. It is the perception of the illegitimacy or marginality of the goat activities by many stake holders and institutions [8], [9], [10]. In regions and countries where goats are considered as dynamic and structured (the goat milk sector in France, Spain, Netherlands, the cashmere goat sector in China, the Boer goat meat sector), the models were industrial models following classical logics developed in other livestock sector (based on intensification and high inputs).

There is not an approach for developed countries or regions on one side and another one for emerging situations. Basically, the innovation and research systems to implement will not be different in developed countries and in project to fight poverty. Goat Innovation Systems must be built with all stake holders, with politicians, with local organizations, and favor cooperative research. This research is not a routine; it is not "business as usual". We are facing a real revolution and this revolution is necessary to favor a significant development of goats where ever goats have favorable conditions (markets, local skills, resources...). I have coordinated a study for IFAD with the International Goat Association, to identify the success factors of pro-poor goat projects. This study shows that to invest on goats can be profitable and impact to fight poverty and favor rural development. It is not THE solution to poverty because many constraints other than market ones could limit their development and success but there are many pathways to develop [5]. The indicators, we have identified show also that main success factors are the construction of strong relations and interactions between all the stake holders including the scientists and that governance has to be often improved.

With this approach, the orientations for research on goat related projects have been re-defined: We need to produce more high quality knowledge and references on local forage resources, local breeds, health control but also collective organization, economics and innovation processes. The need for knowledge on the governance of socio - technical involving goats would require more specific researches and in all cases technical science has to be crossed with social science

All these elements have shown that our initial question, what are the links between industry, science and rurality for the goat sectors was fully pertinent. We have today the theoretical scientific concepts and operational more participative methods to update our visions, redefine our scientific priorities and contribute operationally to improve the role of goats.

\section{REFERENCES}

[1] Krugman P., 2009, Pourquoi les crises reviennent toujours, Editions du Seuil, Paris.

[2] Jackson, Tim, 2009; Prosperity without growth; the transition to a sustainable economy. Sustainable Development Commission. 
[3] IAASTD ; 2008. Agriculture at a cross roads; Analytic report global report ; http://www.agassessment.org/reports/IAASTD/EN/Agriculture\%20at\%20a

\%20Crossroads Global\%20Report\%20(English).pdf

[4] Klerkx, L., Van Bommel, S., Bos, B., Holster, H., Zwartkruis, J., Aarts, N. (2012). Design process outputs as boundary objects in agricultural innovation projects: functions and limitations. Agricultural Systems 113, 39-49. »

[5] Amankwah, K., Klerkx, L., Oosting, S.J., Sakyi-Dawson, O., Van der Zijpp, A., Millar, D. (in press). Diagnosing constraints to market participation of small ruminant producers in Northern Ghana: an innovation systems analysis. NJAS-Wageningen Journal Of Life Sciences ")

[6] Cowan R. et Gunby P. (1996). Sprayed to death: Path dependence, lock-in and pest control., Economic Journal 106(436), 521-43.

[7] Baret, Ph., 2009. Intervention de Philippe Baret, Professeur de Génétique à l'UCL au congrès d'Economie et d'Ecologie de Charleroi du 3 mai 2009.

http://www.dailymotion.com/video/x97exi philippe-baret-au-congres-ecologie news

[8] Dubeuf, J-P, 2005; Structural, market and organisational conditions for a development of goat dairy production systems; in "Plenary papers of the 8th International Conference on Goats ", Small Ruminant Research, 60; 1-2.

[9] Dubeuf, J-P., Morand-Fehr, P., Rubino, R., 2004. Situation, changes and future of goat industry around the world. Small Ruminant Research 51, 165-73.

[10] Morand-Fehr P; Boutonnet JP; Devendra C; et al., 2002; Strategy for goat farming in the 21st century. Conference: 20th Anniversary Meeting of the IGA/Annual Conference of the EAAP Location: CAIRO, EGYPT 